\title{
Depression, anxiety, and stress among medical students of College of Medicine, Hawler Medical University, Erbil, Iraq
}

Accepted: 3/6/2018

\begin{tabular}{l}
\hline \multicolumn{1}{c}{ Ava Ghazi Rasheed $^{1 *}$ Asmaa Ghanim Hussein $^{2}$} \\
\hline Abstract \\
Background and objective: Students of the college of medicine involve in a hard study \\
and training for six years; which might adversely affect the student's mental health and \\
physical condition. This study aimed to identify the prevalence of depression, anxiety, \\
and stress among medical students, and its association with different sociodemographic \\
variables.
\end{tabular}

Methods: A cross-sectional study was conducted among students of the College of Medicine, Hawler Medical University from April to May 2017. This study included a randomly selected sample of 288 students. The Depression, Anxiety, and Stress Scale-21 (DASS-21) questionnaire was used to collect data. The statistical package for the social sciences was used for data analysis. Pearson Chi-square and Fisher's Exact Test were used to finding the association between various variables and depression, anxiety, and stress.

Results: The prevalence of depression, anxiety, and stress among medical students were $52.1 \%, 62.5 \%$, and $45.1 \%$, respectively. Male students were found to be more depressed than female students $(63.6 \%$ vs. $42.3 \%)$ with a statistically significant association $(P<0.001)$. Anxiety and stress were not significantly associated with gender. Anxiety among students from rural areas $(88.9 \%)$ was significantly $(P=0.021)$ higher than students from urban areas (60.7\%). The association of depression, anxiety, and stress with other variables was not significant.

Conclusion: The prevalence of depression, anxiety, and stress among students was high. Male students were regarded as a risk factor for depression, while students from the rural areas were regarded at risk of anxiety.

Keywords: Depression; Anxiety; Stress; Medical students.

\section{Introduction}

The period in which people transmit from adolescent to adulthood is a critical, stressful, and transitory period; university students are those special people that were enduring this period. ${ }^{1}$ Students of the college of medicine involved in a hard study and training for six years, during this time they should acquire adequate skills, attitudes, and professional knowledge, to independently deal with life-long professional challenges, this may adversely affect the student's mental health and physical condition. ${ }^{2}$ By using several instruments, high rates of psychological morbidity among medical students have been reported. ${ }^{3}$ Most probably, these findings are related to social, financial, and academic demands, that put on students by the nature of the college environments, and by other issues related to student's lifestyle. ${ }^{4}$ Depression is a common mental disorder. An individual with depression presents with depressed mood, loss of pleasure or interest, disturbed sleep or appetite, feelings of guilt or low selfworth, decreased energy, and poor concentration. ${ }^{5}$ Fear is the emotional response to real or perceived imminent threat, whereas anxiety is anticipation of

${ }^{1}$ Directorate of Health, Erbil, I raq.

2 Department of Psychiatry, College of Medicine, Hawler Medical University, Erbil, I raq.

* Correspondence: ava.ghazy@gmail.com 
future threat. ${ }^{6}$ Stress is "the nonspecific response of the body to any demand". 7 It is a natural reaction that individual experiences and it is a part of physiological nature of the human body in response to the perceived threat or danger. ${ }^{8}$ Stress during education has a negative impact on learning and cognitive functioning. ${ }^{9}$ When exposure to stress prolonged over a long periods, this may impair immune system and can cause physical and mental disorders. ${ }^{10}$ Therefore, this study aimed to identify the prevalence of depression, anxiety, and stress among medical students of the College of Medicine of Hawler Medical University, and its association with different sociodemographic variables.

\section{Methods}

A cross-sectional study was conducted on students of all academic years at the College of Medicine, Hawler Medical University from April to May 2017. The total number of students of the College of Medicine during the study year 2016/2017 was 1001. The minimum recommended sample size was 278 students from the 1001 students, measured by using the sample size calculator program. The information that were entered into the program included a maximum acceptable error of $5 \%$, desired confidence level of $95 \%$, and response distribution of $50 \%{ }^{11}$ However, 700 students had been selected through stratified random sampling in which the first seven students from each ten had been selected by using the list of students taken from the registration department. A similar number of questionnaires had been distributed among the selected students to overcome the non-respondents and questionnaires with missed data. Out of 700 distributed questionnaires, 430 were returned; 142 of them had been excluded (122 included missed data, and 20 had either chronic medical diseases or known psychiatric illnesses or both of them). In the end, the remained number of the questionnaires was 288 only. This study was approved by the Ethics Committee and Scientific Research Units in Kurdistan Board of Medical Specialties (KBMS). Administrative approval was taken from the College of Medicine, Hawler Medical University, and written informed consent was obtained from all participants before filling the questionnaires. A selfadministered predesigned questionnaire was used to assess sociodemographic data of the students, in addition to other variables like smoking and personal history of the chronic medical disease (like diabetes mellitus and hypertension) and psychiatric illness (Like depression, generalized anxiety disorder, and bipolar disorder). All students of the College of Medicine of Hawler Medical University were included, and any student was complaining of any chronic medical diseases or psychiatric illnesses was excluded from the study. Depression, anxiety, and stress were assessed by using the standardized Depression Anxiety Stress Scale-21 Items (DASS21). This questionnaire is a set of three self-report scales designed to measure the emotional states of depression, anxiety, and stress. Each of the three DASS-21 scales contains seven items; divided into subscales with similar content. ${ }^{12}$ The depression scale assesses devaluation of life, selfdeprecation, dysphoria, and hopelessness, lack of interest and involvement, inertia and anhedonia. The anxiety scale assesses autonomic arousal, situational anxiety; subjective experience of anxious affect and skeletal muscle effects, the stress scale is sensitive to levels of chronic nonspecific arousal. It assesses nervous arousal, being easily upset/agitated, and difficulty relaxing, impatient and irritable/ over-reactive. Scores for depression, anxiety, and stress are calculated by summing the scores for the relevant items. The socioeconomic status of the participant was determined through the number of years of formal education of both father and mother, number of family members, type of housing, e.g., owned or 
rented, number of rooms, possession of the car, and monthly income. This system quoted with modifications from other studies. ${ }^{13}$ After explaining the aim of study for the participants and ensuring the confidentiality for all of them, the self-administered questionnaires were distributed. Filling the questionnaire was taking about 12 to 15 minutes. All demographic data and questionnaire results were registered in a special inventory and analyzed by using the statistical package for the social sciences (version 21.0 for Windows). We used the Chi-square test statistic $\left(x^{2}\right)$ to find the significance of the association between various variables and depression, anxiety, and stress. When the expected count of more than $20 \%$ of the cells of the tables was less than 5, Fisher's exact test was used. When the $P$ value was $<0.05$, it was considered statistically significant.

\section{Results}

The range of participant's age was between 17 to 26 years. Other sociodemographic characteristic features are shown in Table 1. The prevalence of depression, anxiety, and stress among medical students was $52.1 \%, 62.5 \%$, and $45.1 \%$ respectively. Depression was found to be more among males than females (63.6\% vs. $42.3 \%, P<0.001)$. Regarding anxiety and stress, there was no significant association with gender. Anxiety among students from rural areas (88.9\%) was significantly higher than students from urban areas (60.7\%), $P=0.021$. Otherwise, the association of depression, anxiety, and stress with other variables was not significant.

Table 1: Sociodemographic characteristics of the students.

\begin{tabular}{|c|c|c|c|}
\hline Characteristics & & Number & (\%) \\
\hline \multirow[t]{2}{*}{ Gender } & Males & 132 & (45.8) \\
\hline & Female & 156 & (54.2) \\
\hline \multirow[t]{3}{*}{ Marital State } & Single & 274 & (95.1) \\
\hline & Married & 13 & $(4.5)$ \\
\hline & Separated & 1 & $(0.3)$ \\
\hline \multirow[t]{6}{*}{ Stage of study } & First stage & 46 & $(16.0)$ \\
\hline & Second Stage & 41 & $(14.2)$ \\
\hline & Third Stage & 40 & (13.9) \\
\hline & Fourth Stage & 55 & (19.1) \\
\hline & Fifth Stage & 58 & $(20.1)$ \\
\hline & Sixth Stage & 48 & $(16.7)$ \\
\hline \multirow[t]{2}{*}{ Residence } & Urban & 270 & (93.8) \\
\hline & Rural & 18 & $(6.3)$ \\
\hline \multirow[t]{4}{*}{ Religion } & Muslim & 266 & $(92.4)$ \\
\hline & Christian & 16 & $(5.6)$ \\
\hline & Yezidi & 1 & $(0.3)$ \\
\hline & Others & 5 & $(1.7)$ \\
\hline \multirow[t]{4}{*}{ Ethnicity } & Kurd & 263 & (91.3) \\
\hline & Arab & 11 & $(3.8)$ \\
\hline & Turkmen & 2 & $(0.7)$ \\
\hline & Other & 12 & $(4.2)$ \\
\hline \multirow[t]{2}{*}{ Smoking } & Not smoker & 267 & $(92.7)$ \\
\hline & Smoker & 21 & $(7.3)$ \\
\hline \multirow[t]{3}{*}{ Socioeconomic Status } & Low Status & 10 & $(3.5)$ \\
\hline & Medium Status & 78 & (27.1) \\
\hline & High Status & 200 & $(69.4)$ \\
\hline Total & & 288 & $(100.0)$ \\
\hline
\end{tabular}


Table 2 to 9 show the association of the variables. depression, anxiety, and stress with

Table 2: Prevalence of depression, anxiety, and stress by gender.

\begin{tabular}{|c|c|c|c|c|c|}
\hline \multirow[b]{2}{*}{ Variables } & & \multicolumn{2}{|c|}{ Gender } & \multirow[b]{2}{*}{$\begin{array}{c}\text { Total } \\
\text { No. (\%) }\end{array}$} & \multirow[b]{2}{*}{$P$ value } \\
\hline & & $\begin{array}{c}\text { Male } \\
\text { No. (\%) }\end{array}$ & $\begin{array}{l}\text { Female } \\
\text { No. (\%) }\end{array}$ & & \\
\hline \multirow[t]{2}{*}{ Depression } & Present & $84(63.6)$ & $66(42.3)$ & $150(52.1)$ & \multirow{2}{*}{$<0.001^{*}$} \\
\hline & Absent & $48(36.4)$ & $90(57.7)$ & $136(47.9)$ & \\
\hline \multirow[t]{2}{*}{ Anxiety } & Present & $88(66.7)$ & $92(59.0)$ & $180(62.5)$ & \multirow{2}{*}{$0.222^{*}$} \\
\hline & Absent & $44(33.3)$ & $64(41.0)$ & $108(37.5)$ & \\
\hline \multirow[t]{2}{*}{ Stress } & Present & $62(47.0)$ & $68(43.6)$ & $130(45.1)$ & \multirow{2}{*}{$0.635^{\star}$} \\
\hline & Absent & $70(53.0)$ & $88(56.4)$ & $158(54.9)$ & \\
\hline
\end{tabular}

${ }^{*}$ Chi-square test

Table 3: Prevalence of depression, anxiety and stress by marital status.

\begin{tabular}{|c|c|c|c|c|c|c|}
\hline \multirow[b]{2}{*}{ Variables } & & \multicolumn{3}{|c|}{ Marital status } & \multirow{2}{*}{$\begin{array}{c}\text { Total } \\
\text { No. (\%) }\end{array}$} & \multirow[b]{2}{*}{$P$ value } \\
\hline & & $\begin{array}{l}\text { Single } \\
\text { No.(\%) }\end{array}$ & $\begin{array}{l}\text { Married } \\
\text { No. (\%) }\end{array}$ & $\begin{array}{c}\text { Separated } \\
\text { No. (\%) }\end{array}$ & & \\
\hline \multirow[t]{2}{*}{ Depression } & Present & $143(52.2)$ & $6(46.2)$ & $1(100)$ & $150(52.1)$ & \multirow{2}{*}{$0.885^{\star}$} \\
\hline & Absent & $131(47.8)$ & $7(53.8)$ & $0(0)$ & 138(47.9) & \\
\hline \multirow[t]{2}{*}{ Anxiety } & Present & 169 (61.7) & $10(76.9)$ & $1(100)$ & $180(62.5)$ & \multirow{2}{*}{$0.529 *$} \\
\hline & Absent & $105(38.3)$ & 3 (23.1) & $0(0)$ & $108(37.5)$ & \\
\hline \multirow[t]{2}{*}{ Stress } & Present & $126(46.0)$ & $4(30.8)$ & $0(0)$ & $130(45.1)$ & \multirow{2}{*}{$0.395^{\star}$} \\
\hline & Absent & $148(54.0)$ & $9(69.2)$ & $1(100)$ & $158(54.9)$ & \\
\hline
\end{tabular}

*Fisher's Exact Test.

Table 4: Prevalence of depression, anxiety, and stress by stage of the study.

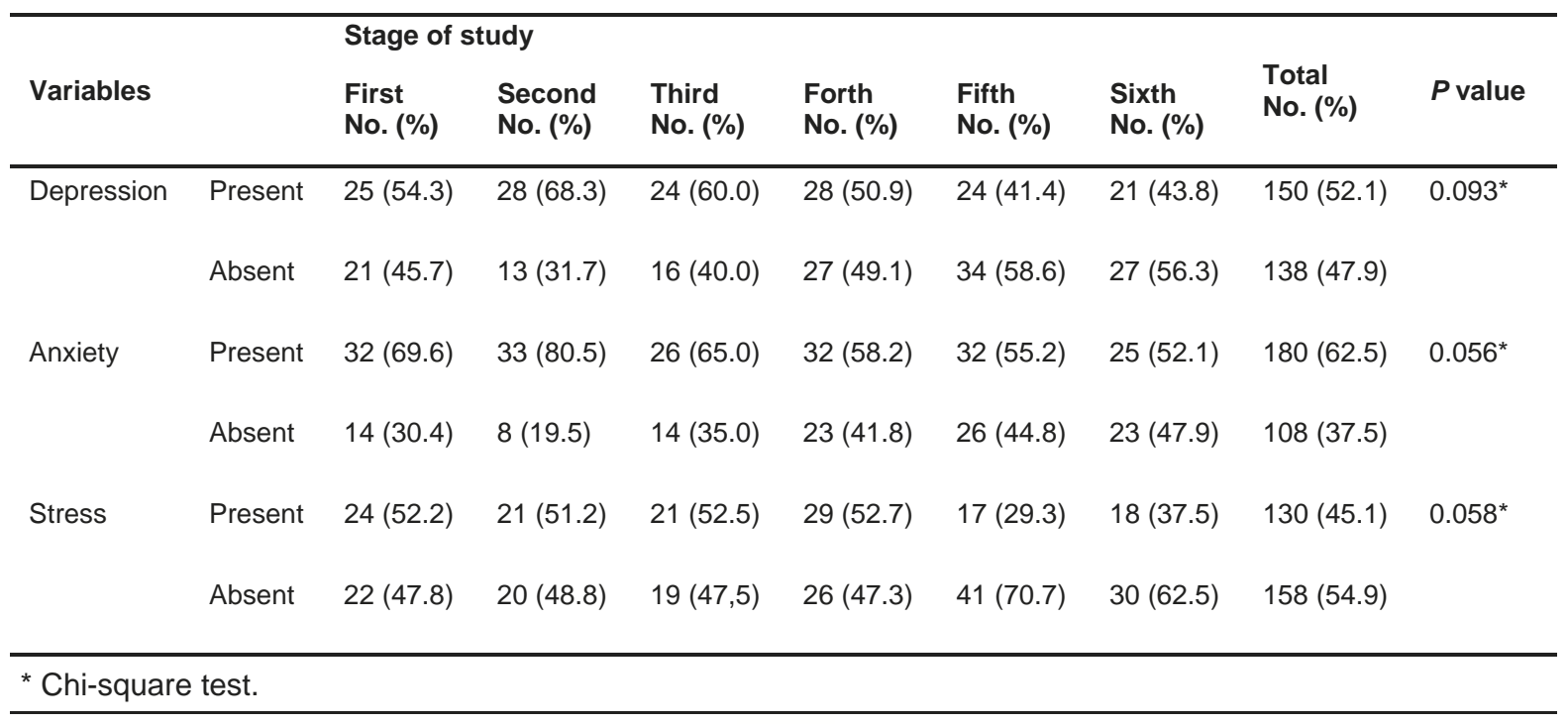


Table 5: Prevalence of depression, anxiety, and stress by residence.

\begin{tabular}{|c|c|c|c|c|c|}
\hline \multirow[b]{2}{*}{ Variables } & & \multicolumn{2}{|c|}{ Residence } & \multirow{2}{*}{$\begin{array}{l}\text { Total } \\
\text { No. (\%) }\end{array}$} & \multirow[b]{2}{*}{$P$ value } \\
\hline & & $\begin{array}{l}\text { Urban } \\
\text { No. (\%) }\end{array}$ & $\begin{array}{c}\text { Rural } \\
\text { No. (\%) }\end{array}$ & & \\
\hline \multirow[t]{2}{*}{ Depression } & Present & $137(50.7)$ & $13(72.2)$ & $150(52.1)$ & \multirow[b]{2}{*}{$0.091^{*}$} \\
\hline & Absent & $133(49.3)$ & $5(27.8)$ & $138(47.9)$ & \\
\hline \multirow[t]{2}{*}{ Anxiety } & Present & $164(60.7)$ & 16 (88.9) & $180(62.5)$ & \multirow[b]{2}{*}{$0.021^{*}$} \\
\hline & Absent & 106 (39.3) & $2(11.1)$ & 108 (37.5) & \\
\hline \multirow[t]{2}{*}{ Stress } & Present & 119 (44.1) & 11 (61.1) & 130 (45.1) & \multirow{2}{*}{$0.221^{*}$} \\
\hline & Absent & 151 (55.9) & 7 (38.9) & 158 (54.9) & \\
\hline
\end{tabular}

${ }^{*}$ Chi-square test.

Table 6: Prevalence of depression, anxiety, and stress by Religion.

\begin{tabular}{|c|c|c|c|c|c|c|c|}
\hline \multirow[b]{2}{*}{ Variables } & & \multicolumn{4}{|c|}{ Religion } & \multirow{2}{*}{$\begin{array}{l}\text { Total } \\
\text { No. (\%) }\end{array}$} & \multirow[b]{2}{*}{$P$ value } \\
\hline & & $\begin{array}{l}\text { Muslims } \\
\text { No. (\%) }\end{array}$ & $\begin{array}{c}\text { Christian } \\
\text { No. (\%) }\end{array}$ & $\begin{array}{c}\text { Yezidi } \\
\text { No. (\%) }\end{array}$ & $\begin{array}{l}\text { Others } \\
\text { No. (\%) }\end{array}$ & & \\
\hline \multirow[t]{2}{*}{ Depression } & Present & $140(52.6)$ & $7(43.8)$ & $0(0)$ & $3(60.0)$ & $150(52.1)$ & \multirow{2}{*}{$0.727^{*}$} \\
\hline & Absent & $126(47.4)$ & $9(56.3)$ & $1(100)$ & $2(40.0)$ & $138(47.9)$ & \\
\hline \multirow[t]{2}{*}{ Anxiety } & Present & $169(63.5)$ & $7(43.8)$ & $1(100)$ & $3(60)$ & $180(62.5)$ & \multirow{2}{*}{$0.345^{\star}$} \\
\hline & Absent & $97(36.5)$ & $9(56.3)$ & $0(0)$ & $2(40)$ & $108(37.5)$ & \\
\hline \multirow[t]{2}{*}{ Stress } & Present & $121(45.5)$ & $6(37.5)$ & $1(100)$ & $2(40)$ & $130(45.1)$ & \multirow{2}{*}{$0.777^{*}$} \\
\hline & Absent & $145(54.5)$ & $10(62.5)$ & $0(0)$ & $3(60)$ & $158(54.9)$ & \\
\hline
\end{tabular}

*Fisher's Exact Test.

Table 7: Prevalence of depression, anxiety, and stress by Ethnicity.

\begin{tabular}{|c|c|c|c|c|c|c|c|}
\hline \multicolumn{8}{|c|}{ Ethnicity } \\
\hline \multicolumn{2}{|l|}{ Variables } & $\begin{array}{l}\text { Kurd } \\
\text { No. (\%) }\end{array}$ & $\begin{array}{c}\text { Arab } \\
\text { No. (\%) }\end{array}$ & $\begin{array}{c}\text { Turkmen } \\
\text { No. (\%) }\end{array}$ & $\begin{array}{l}\text { Others } \\
\text { No. (\%) }\end{array}$ & $\begin{array}{c}\text { Total } \\
\text { No. (\%) }\end{array}$ & $P$ value \\
\hline \multirow[t]{2}{*}{ Depression } & Present & 139 (52.9) & $4(36.4)$ & $1(50.0)$ & $6(50)$ & $150(52.1)$ & \multirow{2}{*}{$0.786^{*}$} \\
\hline & Absent & $124(47.1)$ & $7(63.6)$ & $1(50.0)$ & $6(50)$ & 138 (47.9) & \\
\hline \multirow[t]{2}{*}{ Anxiety } & Present & $168(63.9)$ & $6(54.5)$ & $1(50.0)$ & $5(41.7)$ & $180(62.5)$ & \multirow[b]{2}{*}{$0.343^{*}$} \\
\hline & Absent & 95 (36.1) & $5(45.5)$ & $1(50.0)$ & $7(58.3)$ & 108 (37.5) & \\
\hline \multirow[t]{2}{*}{ Stress } & Present & $119(45.2)$ & $6(54.5)$ & $0(0)$ & $5(41.7)$ & $130(45.1)$ & \multirow{2}{*}{$0.695^{\star}$} \\
\hline & Absent & $144(54.8)$ & $5(45.5)$ & $2(100)$ & 7 (58.3) & 158 (54.9) & \\
\hline
\end{tabular}


Table 8: Prevalence of depression, anxiety, and stress by smoking.

\begin{tabular}{lccccc}
\hline Variables & & \multicolumn{2}{c}{ Smoking } & Total \\
Not-Smoker & Smoker & No. (\%) & P value \\
\hline Nepression & Present & $136(50.9)$ & $14(66.7)$ & $150(52.1)$ & \\
& Absent & $131(49.1)$ & $7(33.3)$ & $138(47.9)$ & $0.181^{*}$ \\
Anxiety & Present & $165(61.8)$ & $15(71.4)$ & $180(62.5)$ & \\
& Absent & $102(38.2)$ & $6(28.6)$ & $108(37.5)$ & $0.485^{\star}$ \\
Stress & Present & $120(44.9)$ & $10(47.6)$ & $130(45.1)$ & \\
& Absent & $147(55.1)$ & $11(52.4)$ & $158(54.9)$ & $0.824^{*}$ \\
& & & & & \\
\hline
\end{tabular}

* Chi-square test.

Table 9: Prevalence of depression, anxiety and stress bysocioeconomic State.

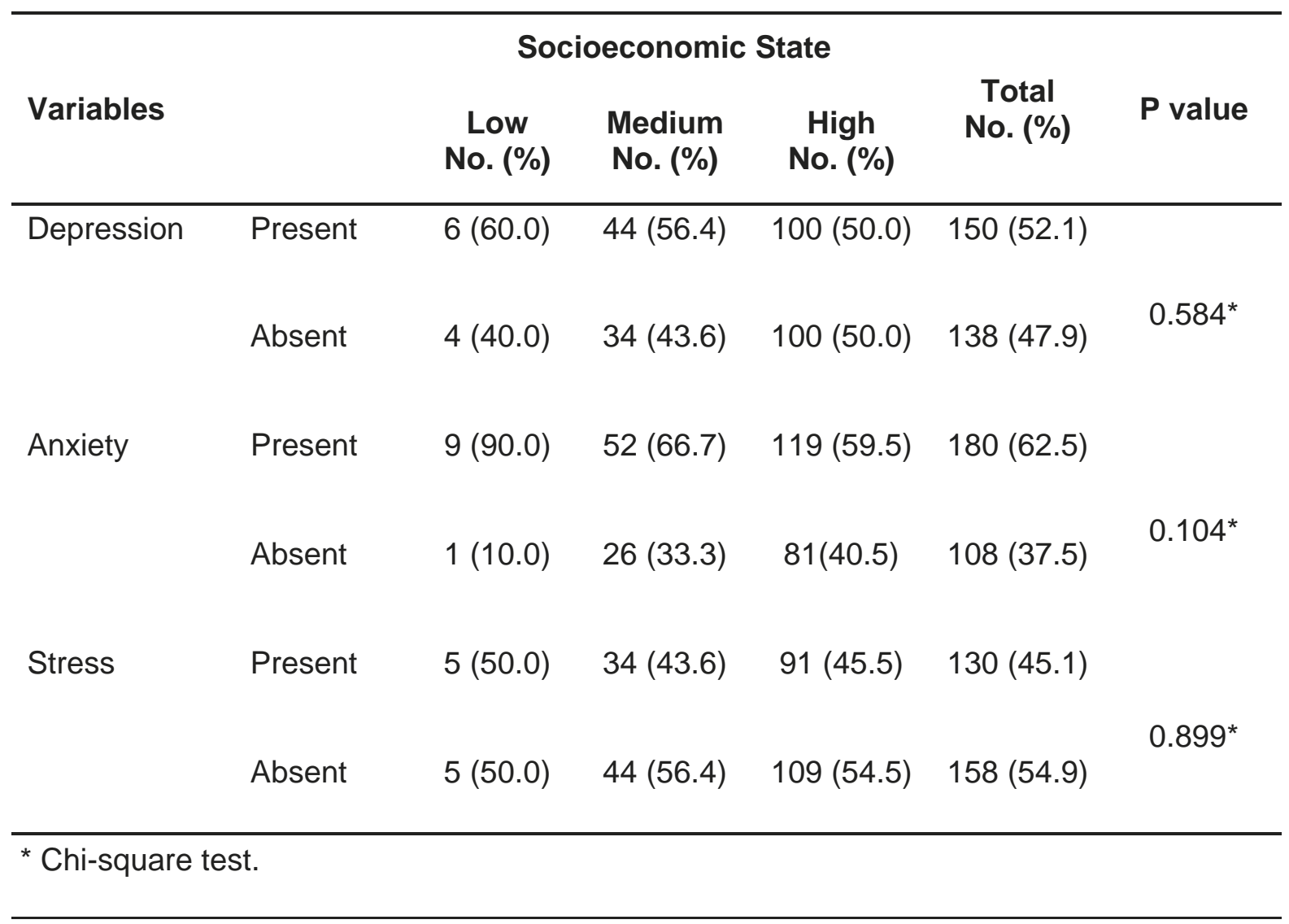




\section{Discussion}

About depression, the results of our study revealed that the prevalence of depression among medical students was $52.1 \%$, which is consistent with a previous study from Urmia, Iran (52.6\%), ${ }^{14}$ another study from Yazd, Iran $(50 \%),{ }^{15}$ and two other studies from in India $(49.1 \%$ and $51.3 \%){ }^{16,17}$ Two studies from Egypt showed that the prevalence of depression was $60.2 \%{ }^{3}$ and $57.9 \%,{ }^{18}$ while it was $43.89 \%$ in another study from Pakistan, ${ }^{4}$ and $49 \%$ in a study from the United States. ${ }^{18}$ Regarding anxiety, our study revealed that the prevalence of anxiety among medical students was $62.5 \%$, which is comparable to other studies. In a cross-sectional study from Egypt which was conducted among medical students and also used DASS-21 Scale, the prevalence was $65 \%{ }^{3}$ Another study from Egypt showed a prevalence of $43.9 \%$ where the Beck depression inventory (BDI) was used and included a sample of 145 students. ${ }^{18} \mathrm{~A}$ cross-sectional study from Pakistan, which used structured a validated questionnaire, the Aga Khan University Anxiety and Depression Scale, showeda prevalence of $43.8 \%{ }^{4}$ A cross-sectional study from India revealed a prevalence of $66.9 \%$. They used the Depression Anxiety Stress Scale DASS-42, with a sample of 353 students. ${ }^{17}$ In Karachi, Pakistan, the prevalence was $70 \%{ }^{9}$ The prevalence was $47.9 \%$ among Al-Qadisia medical students, Iraq. ${ }^{19}$ The prevalence of stress in our study was $45.1 \%$, and the prevalence was $53 \%$ in India, ${ }^{17}$ $44.1 \%$ in Malaysia, ${ }^{20} 61.4 \%$ in Thai, ${ }^{21}$ $62.5 \%$ in Egypt, ${ }^{3} 57 \%$ in Saudi Arabia, ${ }^{22}$ $61.3 \%$ in Iran, ${ }^{23}$ and $47.1 \%$ in Brazil. ${ }^{24}$ Previous studies showed that females develop more anxiety and depression than males in the general population, but data for medical students are conflicting. ${ }^{24}$ We found in our study that depression is more common among males than females $(63.6 \%$ vs. $42.3 \%)$. This is consistent to another study that was conducted on the first-year medical students in an Egyptian public university and used DASS-21, which revealed a higher prevalence of depression among males than females $(53.9 \%$ vs. 46.1\%). ${ }^{25}$ Another study on Malaysian students in a public university using DASS-21also revealed a higher prevalence of depression among males than females (39\% vs. $29.4 \%){ }^{26}$ In other studies among medical students, there was no association between gender and depression. ${ }^{1,14,18,27-29}$ In some other studies, depression was more common among female medical students than males. ${ }^{1,16,17,24,30}$ The most likely explanation of the inconsistent data about gender difference is most likely due to multi factorial, including sociocultural, biological, or variable combinations of each. ${ }^{31}$ Other reasons may be more specific to the culture of our students that males take more responsibilities than females toward many domains of the life and at the time of doing this study there were economic and political crises. This may contribute that males appeared more depressed than females. We found in our study no significant association between anxiety and gender, which is consistent with some studies. ${ }^{26-28}$ However, anxiety was more prominent in females than males in other studies. ${ }^{17,24,25,29,30}$ We found in our study no significant association between stress and gender, which is consistent with many previous studies. ${ }^{8,20,23,28,32-38}$ In contrast, many other studies showed a higher prevalence in female. $3,17,24,25,39-41$ This difference might be related to the differences in the sociocultural background of the participants and using different tools in these studies. Regarding the association with other variables, we found no association between depression and residence. This is consistent with two previous studies. ${ }^{3,4}$ However, there was a significant association of depression with the rural area in another study. ${ }^{25}$ There was no association with marital status, which is consistent with two previous studies. ${ }^{3,4}$ There was also no association with religion, which is in contrast with another study. ${ }^{24}$ Also, no association was found with ethnicity, which is consistent with 
a previous study. ${ }^{24}$ There was no association with smoking, which is in contrast to a previous study that revealed high scores of depression among nonsmoker students. ${ }^{17}$ Also, we found no association with socioeconomic status, which is consistent with a previous study ${ }^{28}$ and is in contrast with another one which revealed a significant association of depression with the low socioeconomic state. ${ }^{3}$ There was no significant association with the stage (class) of the study. Most probably, there are other factors stronger than the effects of these variables that have shown no association which contribute to developing depression, and different studies showed different results. In our study, we found a significant association between anxiety and residency as anxiety score was higher among students from rural areas than urban areas. This result is in contrast with previous studies that revealed no significant association between anxiety and residency. 3,4,19,25 This difference may be due to using different tools by our study and other, and sociocultural factors like the bad situation of public transport and living far away from their families. There was no significant association with the marital state, which is consistent with other studies. $^{3,4}$ There was no association with religion and ethnicity, which is also consistent with another study. ${ }^{24}$ We found no association with smoking, while in one study, anxiety was associated with non-smoking. ${ }^{17}$ There was no association with socioeconomic status as in two previous studies. ${ }^{3,28}$ Regarding stress, we found no association between stress and the residence like in other studies.,42 However, another study revealed that students from rural areas had more stress than from urban areas. ${ }^{25}$ There was no association with the marital status, which is consistent with one previous study, ${ }^{20}$ but in contrast to two other studies, which revealed that married students were less prone to stress., ${ }^{3,23}$ There was no association with religion as in another study. ${ }^{24}$ and no association with ethnicity as in other studies. ${ }^{24,43}$ There was no association with smoking, which is in contrast to two other studies, one of them revealed more stress among nonsmoker, ${ }^{17}$ while the second one revealed more stress among smoker students. ${ }^{44}$ There was no association with the socioeconomic status, which is consistent with another study. ${ }^{28}$ while is in contrast to two other studies: one of them revealed more stress among low socioeconomic status, ${ }^{3}$ while in the second one there was more stress among high socioeconomic status. ${ }^{8}$ Most probably, there are many factors contributed in revealing this high prevalence of depression, anxiety, and stress among medical students. They may be related to the effects of economic and political crises in our country, which has started about three years before doing this study and continued even after that, and the student's perspective toward them. The nature of college programs of the teaching inside the college might have a great role. There might be more personal causes, which need more exploration in further future studies to reach to the more precise causes behind it. This study is limited by having a high non-response rate, which may have a significant effect on the results because out of 700 distributed questionnaires, only 430 were returned, and 122 of them included missed data. To identify the secondary causes of depression, anxiety, and stress (organic causes), we need a complete history and thorough physical examination. The number of immigrant students was not identified; this may have a significant effect on the results. We depended on the participants, to know if they are complaining from any chronic medical illness or psychiatric illness, for exclusion.

\section{Conclusion}

High prevalence of depression, anxiety, and stress among medical students might mean a high pressure on medical student's mental health and might cause a negative 
impact on student's performance. This may be related to the nature of college programs of the teaching, students perspective toward economic and political crises in our country, or other more personal causes which need more exploration in further future studies.

\section{Competing interests}

The authors declare that they have no competing interests.

\section{References}

1. Sarokhani D, Delpisheh A, Veisani $Y$, Sarokhani MT, Manesh RE, Sayehmiri K. Prevalence of Depression among University Students: A Systematic Review and Meta-Analysis Study. Depress Res Treat 2013; 2013:373857.

2. Kulsoom B, Afsar NA. Stress, anxiety, and depression among medical students in a multiethnic setting. Neuropsychiatr Dis Treat 2015; 11:1713-22.

3. Abdel Wahed WY, Hassan SK. Prevalence and associated factors of stress, anxiety and depression among medical Fayoum University students. Alexandria J Med 2017; 53:77-84.

4. Jadoon NA, Yaqoob R, Raza A, Shehzad MA, Zeshan SC. Anxiety and depression among medical students: A cross-sectional study. J Pak Med Assoc 2010; 60(8):699-702.

5. Marcus M, Yasamy MT, Ommeren MV, Chisholm $\mathrm{D}$, Saxena SH. Depression: a global public health concern. Proceedings of the 65th World Health Assembly 2012; Geneva, Switzerland. World Health Organization; 2012.

6. American Psychiatric Association. Diagnostic and Statistical Manual of Mental Disorders. $5^{\text {th }}$ ed. Arlington, VA: American Psychiatric Association; 2013. P.189.

7. Fink G. Stress: Definition and History. Elsevier Ltd; 2009. P.551.

8. Shah C, Trivedi RS, Diwan J, Dixit R, Anand AK. Common stressors and coping of stress by medical students. J Clin Diagn Res 2009; 3:1621 $-6$.

9. Khan MS, Mahmood S, Badshah A, Ali SU, Jamal Y. Prevalence of Depression, Anxiety and their associated factors among medical students in Karachi, Pakistan. J Pak Med Assoc 2006; 56(12):583-6.

10. Houtman I, Jettinghoff K, Cedillo L. Raising Awareness of Stress at Work in Developing Countries: a modern hazard in a traditional working environment: advice to employers and worker representatives. WHO; 2007. P. 22.

11. Raosoft. Sample Size Calculator 2016. (Accessed November 7, 2016, at http://www.raosoft.com/samplesize.html).
12. Lovebird SH, Lovebird PF. Manual for the Depression Anxiety and Stress Scales. 2nd ed. Sydney. Psychology Foundation; 1995.

13. Shabu SA, Al-Tawil NG. Prevalence of Childhood Obesity among a Sample of Basic Education School Children in Erbil City. MEJFM 2012; 10(10):4-13.

14. Aghakhani N, Nia HS, Eghtedar S, Rahbar N, Jasemi M, Zadeh MM. Prevalence of depression among students of Urmia University of Medical Sciences (Iran). Iran J Psychiatry Behav Sci 2011; 5(2):131-5.

15. Lotfi MH, Aminian AH, Ghomizadea A, Zarea S. Prevalence of depression amongst students of Shaheed Sadoughi University of Medical Sciences, Yazd, Iran. IJPBS 2010; 4(2):51-5.

16. Singh A, Lal A, Singh S. Prevalence of depression amongmedical students of a private medical college in India. OJHAS 2010; 9(4):8.

17. Iqbal S, Gupta S, Venkatarao E. Stress, anxiety \& depression among medical undergraduate students and their socio-demographic correlates. Indian J Med Res 2015; 141(3):354-7.

18. Ibrahim MB, Abdelreheem MH. Prevalence of anxiety and depression among medical and pharmaceutical students in Alexandria University. Alexandria J Med 2015; 51:167-73.

19. Suhail HJ. Prevalence of Anxiety among Al-Qadisia Medical Students. KJNS 2015; 5(1).

20. Johari $A B$, Hassim IN. Stress and coping strategies among medical students in National University of Malaysia, Malaysia University of Sabah and University Kuala Lumpur Royal College of Medicine Perak. J Community Health 2009; 15:(2):106-15.

21. Saipanish R. Stress among medical students in a Thai medical school \{Abstract\}. Med Teach 2003; 25(5):502-6.

22. Abdulghani HM. Stress and depression among medical students: A cross sectional study at a Medical College in Saudi Arabia. Pak J Med Sci 2008; 24(1):12-7.

23. Koochaki GM, Charkazi A, Hasanzadeh A, Saedani M, Qorbani M, Marjani A. Prevalence of stress among Iranian medical students: a questionnaire survey. East Mediterr Health $\mathrm{J}$ 2011; 17(7):593-8.

24. Moutinho ID, Maddalena NP, Roland RK, Lucchetti AG, TiBiriçÁ1 SC, Ezequiel OS, Lucchetti $G$ et al. Depression, stress and anxiety in medical students: A cross-sectional comparison between students from different semesters. Rev Assoc Med Bras 2017; 63(1):218.

25. Abdallah AR, Gabr HM. Depression, anxiety and stress among first year medical students in an Egyptian public university. Int J Med Med Sci 2014; 2(1):11-9.

26. Mohammed M, Hayati KS, Salmiah MS. Coping with Depression, Anxiety, and Stress: A Cross-Sectional Study among Malaysian 
2016; 15(11):83-95.

27. Modi K, Kumar D. Anxiety and depression in medical students and its association with coping method adopted by them. IJRRMS 2013; 3(2); 20-2.

28. Kunwar D, Risal A, Koirala S. Study of Depression, Anxiety and Stress among the Medical Students in two Medical Colleges of Nepal. KUMJ 2016; 53(1):22-6.

29. Saravanan C, Wilks R. Medical students' experience of and reaction to stress: The role of depression and anxiety. Scientific World Journal 2014; 737382.

30. Masood A, Rashid S, Musarrat R, Mazzahir Sh. Nonclinical depression and anxiety as predictor of academic stress in medical students. IJMRHS 2016; 5(S):391-7.

31. Amr M, El Gilany A, El-Hawary A. Does gender predict medical students' stress in Mansoura, Egypt? Med Educ Online 2008; 13:12.

32. Kalra R, Mutalik NR, Vinod A, Moni SH, Choudhari SB, Bhogale GS. Perceived stress and coping profile of undergraduate medical students: A cross sectional study. Int J Indian Psychol2016; 4(1):56-63.

33. Ben Loubir D, Serhier Z, Diouny S, Battas O, Agoub M, Bennani OM. Prevalence of stress in Casablanca medical students: a cross-sectional study. Pan Afr Med J 2014; 19:149.

34. Yussuf AD, Issa BA, Ajiboye PO, Buhari ON, The correlates of stress, coping styles and psychiatric morbidity in the first year of medical education at a Nigerian University. Afr J Psychiatry 2013; 16:206-15.

35. Yusoff MS, Yee LY, Wei LH, Siong TC, Meng LH, Bin LX, et al. A study on stress, stressors and coping strategies among Malaysian medical students. IJSR 2011; 1(2):45-50.

36. Madhyastha S, Latha KS, Kamath A. Stress and coping among final year medical students. AP J Psychol Med 2014; 15(1):74-80.

37. Oku AO, Owoaje ET, Oku OO, Ikpeme BM. Prevalence of stress, stressors and coping strategies among medical students in a Nigerian medical school. Afr J Med Health Sci 2015; 14:29 -34 .

38. Eva EO, Islam MZ, Mosaddek AM, Rahman MF, Rozario RJ, Iftekhar $\mathrm{AH}$, et al. Prevalence of stress among medical students: a comparative study between public and private medical schools in Bangladesh. BMC Res Notes 2015; 8:327.

39. Siddiqui AF, Al-Amri SA, Al-Katheri AA, Al-Hassani KH. Perceived stress in Saudi undergraduate medical students. J Med Allied Sci 2017; 7(1):41-7.

40. Gazder DP, Ahmad F, Danish SH. Stressors, coursework stress and coping strategies among medical students in a private medical school of Karachi, Pakistan. Educ Med J 2014; 6(3):e22-9.
41. Bamuhair SS, AlFarhan Al, Althubaiti A, Agha S, urRahman S, Ibrahim NO. Sources of stress and coping strategies among undergraduate medical students enrolled in a problem-based learning curriculum. J Biomed Educ 2015; 2015.

42. Shaikh BT, Kahloon A, Kazmi M, Khalid $H$, Nawaz K, Khan NA, et al. Students, stress and coping strategies: A case of Pakistani Medical School. Educ Health (Abingdon) 2004; 17(3):346 $-53$.

43. Sherina MS, Rampal L, Kaneson N. Psychological stress amongundergraduate medical students. Med J Malaysia 2004; 59(2):207-11.

44. Al-DubAi SA, Al-Naggar RA, Alshagga MA, Rampal KG. Stress and coping strategies of students in a medical faculty in Malaysia. Malaysian J Med Sci 2011; 18(3):57-64. 